\title{
Glutamate Carboxypeptidase 2
}

National Cancer Institute

\section{Source}

National Cancer Institute. Glutamate Carboxypeptidase 2. NCI Thesaurus. Code C17796.

Glutamate carboxypeptidase 2 (750 aa, $~ 84 \mathrm{kDa}$ ) is encoded by the human FOLH1 gene.

This protein plays a role in the mediation of folate metabolism. 